\title{
Elemental concentration via portable x-ray fluorescence spectrometry: Assessing the impact of water content
}

\section{Concentração elementar obtida por espectrometria de fluorescência de raios-x portátil: Efeito da umidade}

\author{
Monna Lysa Teixeira Santana' (D), Geila Santos Carvalho' (D), \\ Luiz Roberto Guimarães Guilherme ${ }^{1}(\mathbb{D})$, Nilton Curi ${ }^{*}(\mathbb{D})$, Bruno Teixeira Ribeiro ${ }^{1}$
}

'Universidade Federal de Lavras/UFLA, Departamento de Ciência do Solo/DCS, Lavras, MG, Brasil

* Corresponding author: niltcuri@ufla.br

Received in December 13, 2018 and approved in April 16, 2019

\begin{abstract}
Portable X-ray fluorescence (pXRF) analysis can be considered one of the main recent advances for chemical characterization of earth materials. The water content of the samples can affect the pXRF performance. As a novelty, we aimed to establish relationships (linear regression) between the effect of water content on pXRF results and atomic number ( $Z$ ) of the elements. Three certified reference materials (CRM) were investigated: OREAS 100a, OREAS 101a, and OREAS $101 \mathrm{~b}$. These materials were saturated $\left(0.68 \mathrm{~g} \mathrm{~g}^{-1}\right)$ with distilled water and left to air-dry naturally. During the drying, the elemental concentrations (C) were determined at different water contents using a pXRF spectrometer. For each water content, the ratio $C_{\text {wet }} / C_{\text {dry }}$ was determined and plotted against the water content. The attenuation coefficient $(\sigma)$ was also determined. High $\sigma$ values mean more influence of water content upon measurement element concentration. The obtained recovery rates allowed a qualitative determination. The concentration for the most elements reduced linearly with increasing water content. A predictable behavior of the water content on pXRF results as function of atomic number was not found. Elements identified by La spectral line with highest $\mathrm{Z}$ were more impacted by water content than elements identified by $\mathrm{Ka}$ line with lowest $\mathrm{Z}$. Ti, $\mathrm{Cr}$ and Fe was not significantly influenced by water content, and Sr was the most impacted. Our findings contribute to decision-making before characterization earth materials via pXRF, obliging the use of dry samples for determination of impacted elements or by using moisture-corrected data.
\end{abstract}

Index terms: Proximal sensors; X-ray scattering; spectroscopy analysis.

\section{RESUMO}

A fluorescência de raios-X portátil (pXRF) pode ser considerada como um dos principais avanços para a caracterização química de diferentes materiais. A umidade das amostras pode afetar o desempenho dessa análise. Assim, foi realizado um ensaio para verificar o efeito da umidade na concentração elementar obtida via pXRF. Como inovação, objetivou-se estabelecer relações (regressão) entre o efeito da umidade nos resultados do pXRF e o número atômico (Z) dos elementos. Três amostras de referência certificadas (CRM) foram utilizadas: OREAS 100a, OREAS 101a e OREAS 101b. As amostras foram saturadas com água destilada $\left(0.68 \mathrm{~g} \mathrm{~g}^{-1}\right)$ e secas à temperatura ambiente. Durante a secagem, as concentrações dos elementos (C) foram determinadas nas amostras com diferentes teores de água usando um pXRF. Para cada teor de água, a relação $C_{\text {úmido }} / C_{\text {seco }}$ foi determinada e plotada em função da umidade, ajustando-se modelos lineares e exponenciais. O coeficiente de atenuação $(\sigma)$ também foi calculado. Altos valores de $\sigma$ significam maior influência da umidade. As porcentagens de recuperação obtidas permitiram uma determinação qualitativa, entretanto, a concentração da maioria dos elementos estudados reduziu significativamente com o aumento da umidade. Não foi possível a modelagem do efeito da umidade, avaliada pelo $\sigma$, em função do número atômico. Comparativamente, elementos com elevado número atômico e identificados pela linha La foram mais impactados que elementos com números atômicos menores identificados pela linha $\mathrm{Ka}$. Ti, $\mathrm{Cr}$ e Fe não foram significativamente influenciados pela umidade e o Sr foi o mais impactado. Os resultados encontrados contribuem para a tomada de decisão antes da caracterização utilizando pXRF, obrigando o uso de amostras secas para aqueles elementos impactados ou o uso de fatores de correção.

Termos para indexação: Sensores proximais; espalhamento de raios-X; análise espectrométrica.

\section{INTRODUCTION}

The total elemental composition of different materials can be obtained by X-ray fluorescence analysis
(Jenkins, 1932; Potts, 2008). In recent years, technological advancements allowed the miniaturization of X-ray fluorescence equipment. Nowadays, there are many models of portable X-ray fluorescence equipment (pXRF) 
available (Gazley; Fisher, 2014; Weindorf et al., 2014). The pXRF has been largely and successfully used for industrial, geological, agricultural and environmental purposes (Parsons et al., 2013; Widana; Priadi, 2015; McNulty et al., 2018; Yarbrough et al., 2018). The pXRF analysis is fast, non-destructive, environmentally friendly, allowing the determination of several elements simultaneously (e.g., from $\mathrm{Mg}$ to $\mathrm{U}$ ) in-situ or ex-situ within the order of seconds. The Soil Science has been greatly benefited from pXRF analysis (Ribeiro et al., 2017; Ribeiro et al., 2018; Santana et al., 2018; Silva et al., 2018; Mancini et al., 2019, Weindorf et al., 2014; Stockmann et al., 2016).

The principle of X-ray fluorescence analysis is the emission of secondary X-rays by the sample when it is irradiated by a source of primary X-rays (Kalnicky; Singhvi, 2001; Gazley; Fisher, 2014). This occurs when electrons are shifted from inner to outer shells. As a result, to fill inner-shell vacancies the outer electrons move to them. At this moment, energy is released in form of fluorescence. The emitted secondary X-rays are characteristic for each element (spectral signature). The emitted energy ( $\mathrm{keV}$ ) and wavelength are used to identify the element and the intensity of fluorescence allows its quantification (Margui; Grieken, 2013; Weindorf et al., 2014). It is reasonable to consider that the presence of water between the particles to be analyzed would act as a physical barrier for primary X-rays and/or scattering the secondary X-rays (Ge et al., 2005). As a consequence, the obtained concentration may be underestimated (Sahraoui; Hachicha, 2017; Schneider et al., 2015). The effect of water content on pXRF results is still quite divergent in the literature.

The water content during pXRF analysis is considered the main factor affecting the accuracy of derived element concentrations. There is not a consensus about which elements are more influenced by water content and how much water can influence the pXRF analysis. Elements with atomic number $(\mathrm{Z})<26$ seem to be more influenced (Ge et al., 2005; Weindorf et al., 2014). However, $\mathrm{Zr}(\mathrm{Z}=40)$ and $\mathrm{Pb}(\mathrm{Z}=82)$ were also influenced by water content (Hürkamp et al., 2009; Shuttleworth et al., 2014; Hangen; Vieten, 2016). In some Brazilian soil samples the elements $\mathrm{Si}(Z=14)$ and $\mathrm{Al}(Z=13)$ were much more influenced by moisture than $\mathrm{Ti}(Z=22)$ and $\mathrm{Fe}(\mathrm{Z}=26)$ (Ribeiro et al., 2018). Frequently, non-effect of water content on Fe quantification via $\mathrm{pXRF}$ has been reported (Berger et al., 2009; Stockmann et al., 2016). In general, water content between $5 \%$ and $15 \%$ does not seem to influence the pXRF results (Laiho; Perämäki, 2005; Piorek, 1997; Peinado et al., 2010). Considering the effect of water content on pXRF results, some correction factors have been proposed (Ge et al., 2005; Bastos et al., 2012; Ribeiro et al., 2018) in order to overcome such constraints. The procedures for pXRF analysis of soils and sediments are summarized in the US EPA 6200 method (US EPA, 2007) and by Weindorf and Chakraborty (2016). According to US EPA 6200 method the pXRF results are minimally impacted with moisture up to $0.20 \mathrm{~g} \mathrm{~g}^{-1}(20 \% \mathrm{wt})$.

Thus, we conducted a controlled laboratory experiment using three certified reference materials (CRM) to check for the pXRF results under influence of different water contents. The objectives were to identify elements, which, are more influenced by water content during the $\mathrm{pXRF}$ screening. As a novelty, this work aimed to establish relationships between atomic number and attenuation coefficient $(\sigma)$ based on the Beer-Lambert Law. This parameter indicates how much a given element is influenced by water content. We hypothesized that the water content underestimate the concentration reported by pXRF and this effect decrease as the atomic number of elements increase. If so, the impact of water content as function of atomic number can be modelled.

\section{MATERIAL AND METHODS}

\section{Certified reference materials (CRM)}

For this study, three CRM's for geochemical applications were selected: OREAS 100a, OREAS 101a, and OREAS 101b. These CRM's are U-bearing materials prepared by Ore Research \& Exploration Pty Ltd from geological exploration at Mont Gee, South Australia. The certified values were reported after characterization by different methods: lithium borate fusion for X-ray fluorescence analysis (XRF) and 4-acid digestion (HF, $\mathrm{HCl}, \mathrm{HNO}_{3}$ and $\mathrm{HClO}_{4}$ ) for mass spectrometry inductively coupled plasma (ICPOES/MS). The certified values were obtained at Ore Research \& Exploration website (http:// www.ore.com.au/oreas-reports/).

\section{Experimental setup and pXRF measurements}

Polyvinyl chloride (PVC) rings $(1 \mathrm{~cm}$ high and $5 \mathrm{~cm}$ diameter) situated at the bottom X-ray thin film (prolene film) were used to receive the CRM's. The X-ray thin film was held by a rubber. Thus, the rings were packed (in triplicate) with $13 \mathrm{~g}$ of each CRM's resulting in a CRM thickness of $9 \mathrm{~mm}$. Distilled water $(9 \mathrm{~mL})$ was added to CRM rings until reaching complete saturation. The CRM rings were left under laboratory conditions to air-dry naturally. The pXRF measurements were performed on CRM samples 
at different water contents (from complete wet condition to air-dried condition). The water contents ranged from 0.68 to $0.02 \mathrm{~g} \mathrm{~g}^{-1}$. Before each pXRF measurement the samples were weighted to calculate the water content according to Equation 1:

$$
\mathrm{WC}=\frac{\mathrm{W}_{\mathrm{wet}}-\mathrm{W}_{\mathrm{dry}}}{\mathrm{W}_{\mathrm{dry}}}
$$

Where: $\mathrm{WC}$ is the water content $\left(\mathrm{g} \mathrm{g}^{-1}\right)$; $\mathrm{W}_{\text {wet }}$ is the ring weight ( $\mathrm{g}$ ) containing wet CRM materials; $\mathrm{W}_{\mathrm{dry}}$ is the ring weight $(\mathrm{g})$ containing the equivalent dry CRM materials.

For pXRF measurements a handheld Bruker ${ }^{\mathbb{R}}$ spectrometer S1 Titan LE model was used. The operational conditions were: Rh X-ray tube (4W, 15$50 \mathrm{kV}$, and 5-100 $\mu \mathrm{A}$ ); silicon drift detector (SDD) with resolution $<145 \mathrm{eV}$; Geochem application (Trace Mode); and screening time of $60 \mathrm{~s}$. The dwell time $(60 \mathrm{~s})$ is automatically divided in two phases: i) phase 1 (first $30 \mathrm{~s}$ ): $45 \mathrm{kV}$ is applied and quantified the following elements: from $\mathrm{Mn}$ to U; phase 2 (last $30 \mathrm{~s}$ ): the excitation energy is reduced to $15 \mathrm{kV}$ and quantified the elements: from $\mathrm{Mg}$ to $\mathrm{Ca}$. Using the Bruker ${ }^{\circledR} \mathrm{S} 1$ Data Tool software, the pXRF report and spectral data were analyzed. The following elements were identified and quantified: i) using the $\mathrm{K} \alpha$ spectral line reference: $\mathrm{Mg}, \mathrm{Al}, \mathrm{Si}, \mathrm{P}, \mathrm{Cl}, \mathrm{K}, \mathrm{Ca}, \mathrm{Ti}, \mathrm{Cr}, \mathrm{Mn}, \mathrm{Fe}$, and $\mathrm{Co}$; ii) using the $\mathrm{L} \alpha$ spectral line reference: $\mathrm{Cu}, \mathrm{Rb}, \mathrm{Sr}, \mathrm{Zr}$, $\mathrm{Nb}, \mathrm{Ce}$, and $\mathrm{Bi}$. Thus, in this work the studied elements were called as $\mathrm{K} \alpha$ and $\mathrm{L} \alpha$ elements. The pXRF results obtained using oven-dried $\left(105^{\circ} \mathrm{C}\right)$ samples were used to calculate the recovery percentage taking into account the certified values for CRM's.

The attenuation coefficient $(\sigma)$ proposed by Ge et al. (2005) was calculated for each element and water content according to Equation 2:

$$
\frac{C_{\text {wet }}}{C_{\text {dry }}}=\mathrm{e}^{-\sigma \cdot w C}
$$

Where: $\mathrm{C}_{\text {wet }}$ is the concentration of the element at maximum water content; $\mathrm{C}_{\mathrm{dry}}$ is the concentration of the element in the dry CRM material; $\sigma$ is the attenuation coefficient (non-dimensional); and WC is the water content.

The attenuation coefficient $(\sigma)$ can be calculated from the logarithmic form (Equation 3):

$$
-\sigma=\frac{\left(\ln C_{\text {wet }}-\ln C_{\text {dry }}\right)}{W C}
$$

For each element, the ratio $\mathrm{C}_{\text {wet }} / \mathrm{C}_{\text {dry }}$ was plotted onto the $\mathrm{Y}$ axis and water content (WC) onto the $\mathrm{X}$ axis. Thus, linear and exponential models were adjusted to data using R-studio software and graphs were obtained using Sigma Plot software version 12.5. The attenuation coefficients $(\sigma)$ were correlated to the atomic number of elements.

\section{RESULTS AND DISCUSSION}

\section{Recovery rates of elements quantified by PXRF}

In Table 1 the mean recovery rates of elements for each CRM using pXRF analysis are shown. The best recovery rate was obtained for $\mathrm{Rb}(100 \%)$ in the OREAS 100a. The worst recovery rates were obtained for $\mathrm{Mg}, \mathrm{P}$, $\mathrm{Co}, \mathrm{Ce}$, and $\mathrm{Bi}$. For these elements the pXRF results were significantly higher than the certified reference values. Light elements $(\mathrm{Si}, \mathrm{K}$, and $\mathrm{Ca}$ ) had low recovery rates (below 50\%). XRF analysis becomes more inaccurate for the lightest elements since they have low fluorescence yield and can be influenced by fluorescence of heaviest elements (Magui; Grieken, 2013). The elements Al, Ti, $\mathrm{Cr}, \mathrm{Mn}, \mathrm{Fe}, \mathrm{Cu}, \mathrm{Zn}, \mathrm{Rb}, \mathrm{Sr}, \mathrm{Zr}$, and $\mathrm{Nb}$ had recovery rates between 60 and $200 \%$. In addition, the recovery rates obtained in the three CRM's were similar. A nonsatisfactory recovery (e.g., far from 100\%) may be due to: i) non-proper calibration of the equipment by the manufacturer; and ii) matrix effect causing spectral interference (e.g., $\mathrm{S}$ and $\mathrm{Mo} ; \mathrm{Cl}$ and $\mathrm{Rh} ; \mathrm{As}$ and $\mathrm{Pb} ; \mathrm{V}$ and $\mathrm{Cr}$; Fe and Co) (Kalnicky; Singhvi, 2001).

Sinnesael et al. (2018) using a pXRF Bruker ${ }^{\circledR}$ Tracer IV model and seven CRM's [CCH-1 (Liege University), COQ-1 (United States Geological Survey, USGS), CRM393 (Bureau of Analysed Samples, BAS), CRM512 (BAS), CRM513 (BAS), ECRM-782-1 (BAS) and SRM-1d (National Institute of Standards and Technology, NIST)], found the recovery rates (\%) of Fe, $\mathrm{Mn}, \mathrm{Sr}$, and Ti of 57, 101, 115 and 379, respectively.

NIST standard reference material (2711a), $\mathrm{ERM}^{\circledR}$ (European Reference Materials) CC141, and ISE (International Soil analytical Exchange) were used for quality assurance and control of pXRF analysis using an Olympus model Delta Professional (Caporale et al., 2018). These authors screened during $30 \mathrm{~s}$ (Geochem Application: Soil Mode) and provide contents of $\mathrm{As}, \mathrm{Ca}, \mathrm{Cu}, \mathrm{Cr}, \mathrm{K}, \mathrm{Fe}, \mathrm{Mn}, \mathrm{Ni}$, 
$\mathrm{Pb}, \mathrm{Ti}, \mathrm{Sr}, \mathrm{V}$, and $\mathrm{Zn}$. The recovery rates ranged from 82 to $116 \%$ and the correction factors $\left(\mathrm{pXRF}_{\text {read }} /\right.$ certified value) were determined. Using the NIST standard reference material (278), 12 elements (K, Ca, Ti, Mn, Fe, Zn, Rb, $\mathrm{Sr}, \mathrm{Zr}, \mathrm{Nb}, \mathrm{Pb}$, and $\mathrm{Th}$ ) were identified and quantified using a pXRF Olympus Delta Premium (Ta X-ray tube), Obsidian-soil mode, and the screening time ranged from 5 to $100 \mathrm{~s}$ (Newlander et al., 2015). The highest relative standard errors (RSD - \%) were obtained for Th (29), Zn (19), $\mathrm{Pb}$ (17), and $\mathrm{Mn}$ (10). The authors conclude that the accuracy of pXRF measurement is not influenced by the increase of screening time. However, the screening time can significantly influence the pXRF results, mainly the detection limit and repeatability (Gazley; Fisher, 2014). The different recovery rates found in the literature can be attributed to the intrinsic features of operational conditions and to the different characteristic of samples (soils, sediments, rocks, etc.).
Some agricultural soils were accurately characterized via pXRF analysis (Hu et al., 2014). The authors used a pXRF Niton ${ }^{\circledR}$ XLt 960 model to assess the $\mathrm{As}, \mathrm{Pb}, \mathrm{Cu}$, and $\mathrm{Zn}$ concentrations. The CRM GBW07401 was scanned for $90 \mathrm{~s}$ and the recoveries for $\mathrm{As}, \mathrm{Pb}$, and $\mathrm{Cu}$ ranged from 98 to $109 \%$, and $117 \%$ for $\mathrm{Zn}$. In our work the best recovery rate found for $\mathrm{Zn}$ was $183 \%$ (OREAS $100 \mathrm{a}$ ) (Table 1). As and $\mathrm{Pb}$ were below the detection limit.

\section{Effect of water content on elemental concentration obtained via pXRF}

In Table 2 the significance and $\mathrm{R}^{2}$ values (coefficient of determination) for regression analysis performed between elemental concentration $\left(\mathrm{C}_{\text {wet }} / \mathrm{C}_{\mathrm{dry}}\right)$ ratio and water content are shown. The linear and exponential regression models were significant showing similar $\mathrm{R}^{2}$ values for the three CRM's. Only the elements having recoveries between 60 and $200 \%$ were considered. These

Table 1: Mean recovery rates (\%) of elements identified and quantified by pXRF Bruker ${ }^{\circledR}$ spectrometer S1 Titan LE model.

\begin{tabular}{|c|c|c|c|c|c|c|c|}
\hline \multirow{2}{*}{ Element } & \multirow{2}{*}{ Z } & \multirow{2}{*}{$\begin{array}{l}\text { Spectral } \\
\text { line }\end{array}$} & \multirow{2}{*}{$\mathrm{keV}$} & \multirow{2}{*}{$\begin{array}{c}\text { LOD } \\
\left(\mathrm{mg} \mathrm{kg}^{-1}\right)\end{array}$} & \multicolumn{3}{|c|}{ Recovery (\%) } \\
\hline & & & & & OREAS 100a & OREAS 101a & OREAS $101 \mathrm{~b}$ \\
\hline Mg & 12 & $\mathrm{Ka}$ & 1.254 & 9,000 & 1,589 & 1,243 & 1,084 \\
\hline $\mathrm{Al}$ & 13 & $\mathrm{Ka}$ & 1.486 & 1,150 & 61 & 71 & 65 \\
\hline $\mathrm{Si}$ & 14 & $\mathrm{Ka}$ & 1.740 & 500 & 40 & 37 & 41 \\
\hline $\mathrm{P}$ & 15 & $\mathrm{Ka}$ & 2.010 & 170 & 950 & 2,148 & 431 \\
\hline $\mathrm{K}$ & 19 & $\mathrm{Ka}$ & 3.314 & 55 & 35 & 38 & 40 \\
\hline $\mathrm{Ca}$ & 20 & $\mathrm{Ka}$ & 3.692 & 50 & 22 & 21 & 24 \\
\hline $\mathrm{Ti}$ & 22 & $\mathrm{Ka}$ & 4.512 & 21 & 68 & 66 & 69 \\
\hline $\mathrm{Cr}$ & 24 & $\mathrm{Ka}$ & 5.415 & 30 & 205 & 448 & 380 \\
\hline $\mathrm{Mn}$ & 25 & $\mathrm{Ka}$ & 5.900 & 30 & 68 & 76 & 77 \\
\hline $\mathrm{Fe}$ & 26 & $\mathrm{Ka}$ & 6.405 & 19 & 63 & 63 & 64 \\
\hline Co & 27 & $\mathrm{Ka}$ & 6.931 & 2 & 4,334 & 5,830 & 4,236 \\
\hline $\mathrm{Cu}$ & 29 & La & 0.928 & 5 & 76 & 75 & 78 \\
\hline $\mathrm{Zn}$ & 30 & La & 1.012 & 4 & 183 & 248 & 335 \\
\hline $\mathrm{Rb}$ & 37 & La & 1.692 & 3 & 100 & 118 & 120 \\
\hline $\mathrm{Sr}$ & 38 & La & 1.806 & 4 & 87 & 69 & 75 \\
\hline $\mathrm{Zr}$ & 40 & La & 2.044 & 4 & 87 & 88 & 92 \\
\hline $\mathrm{Nb}$ & 41 & La & 2.169 & 4 & 91 & 133 & 134 \\
\hline $\mathrm{Ce}$ & 58 & La & 4.439 & 35 & 587 & 316 & 319 \\
\hline $\mathrm{Bi}$ & 83 & La & 10.839 & 17 & 14,550 & 9,327 & 12,500 \\
\hline
\end{tabular}

Recovery rate of 100\%: pXRF result is equal to certified reference value; Recovery rate above 100\%: pXRF result is higher than certified reference value; Recovery rate below 100\%: pXRF result is lower than certified reference value. LOD: limit of detection. 
comprise $\mathrm{Al}, \mathrm{Ti}, \mathrm{Cr}, \mathrm{Mn}, \mathrm{Fe}, \mathrm{Cu}, \mathrm{Zn}, \mathrm{Rb}, \mathrm{Sr}, \mathrm{Zr}$, and $\mathrm{Nb}$. The quantification of $\mathrm{Ti}(\mathrm{Z}=22), \mathrm{Cr}(\mathrm{Z}=24)$, and $\mathrm{Fe}$ $(Z=26)$ was not influenced by water content. The tested regression models were not significant for these elements, except for Fe (OREAS 100a linear model), but with low $\mathrm{R}^{2}(0.26)$. For the other elements, a predictable behavior was identified, indicating the effect of water content on elemental concentration obtained by pXRF, as can be seen in Figure 1 indicating a diluting effect of the water content upon element concentration.

For each element, the slopes of regression lines were similar for the CRM's (Figure 1). The L $\alpha$ elements $(\mathrm{Cu}, \mathrm{Zn}, \mathrm{Rb}, \mathrm{Sr}, \mathrm{Zr}$, and $\mathrm{Nb}$ ) showed a steeper slope than the $\mathrm{K} \alpha$ elements ( $\mathrm{Al}, \mathrm{Mn}$, and $\mathrm{Fe}$ ). The slope ranged from $0.65(\mathrm{Zn})$ to $0.75(\mathrm{Zr})$ in the $\mathrm{L} \alpha$ group, and from $0.20(\mathrm{Fe})$ to $0.33(\mathrm{Al})$ in the $\mathrm{K} \alpha$ group. The mean slope for the $\mathrm{L} \alpha$ group was 2.7 times higher than for the $\mathrm{K} \alpha$ group. Taking the slope as a parameter to describe how much the elements concentrations were impacted by the water content, in the $\mathrm{K} \alpha$ group it decreased as follows: $\mathrm{Al}>\mathrm{Mn}>\mathrm{Fe}$. The effect of water content on the quantification of $\mathrm{Fe}$ using pXRF can be considered quite insignificant. A significant effect was observed only for OREAS 100a, but with very low slope and $\mathrm{R}^{2}$ values of regression. For the elements of the L $\alpha$ group the slope declined as follows: $\mathrm{Nb}>\mathrm{Zr}>$ $\mathrm{Rb}>\mathrm{Cu}>\mathrm{Sr}>\mathrm{Zn}$.

Based on the Beer-Lambert Law, the $\sigma$ parameter (Equations 2 and 3) was presumed to assess the effect of water content on elemental concentration obtained via pXRF analysis (Ge et al., 2005). In our work, $\sigma$ was calculated for each element according to Equations 2 and 3 and correlated to atomic number (Z) and X-ray fluorescence energy values (Figure 2). There was not a consistent and predictable relationship between $\sigma$ and atomic number corroborating other works (Sahraoui; Hachicha, 2017; Schneider et al., 2015). Conversely, some works related a consistent relationship between atomic number and the effect of water content on signal reduction, underestimating the results (Ge et al., 2005; Kido et al., 2006).

Parsons et al. (2013) suggested that low-Z elements are predominantly influenced by water content. In contrast, in our study the $\mathrm{K} \alpha$ elements $(\mathrm{Al}, \mathrm{Ti}, \mathrm{Cr}$, $\mathrm{Mn}$, and $\mathrm{Fe}$ ) showed lower $\sigma$ compared to L $\alpha$ elements (Figure 2). This indicates that elements with higher atomic number (e.g., ${ }^{41} \mathrm{Nb}$ ) may be more influenced by water content than lighter elements (e.g., $\left.{ }^{13} \mathrm{Al}\right)$. Screening the surface of undisturbed samples of tropical soils, Si and Al (light elements) were significantly more influenced by increase of water content than $\mathrm{Fe}$ and $\mathrm{Ti}$ (heaviest elements) (Ribeiro et al., 2018). In each group (K $\alpha$ or $\mathrm{L} \alpha$ ), a consistent and predictable relationship between $\sigma$ and atomic number or fluorescence energy values $(\mathrm{keV})$ was not detected. Thus, the effect of water content on elemental concentration obtained via $\mathrm{pXRF}$ might be related to a combination of X-ray fluorescence energy line (keV) and the intrinsic characteristic of the element. Kalnicky and Singhvi (2001) suggested that elements with X-ray energy values smaller than $5 \mathrm{keV}$ are more impacted by water content. This corroborates to our findings. The $\mathrm{L} \alpha$

Table 2: $R^{2}$-values of the regression analysis between $C_{\text {wet }} / C_{\text {dry }}$ ratio and water content (ranging from $0.68 \mathrm{~g} \mathrm{~g}^{-1}$ to air-dry). All regressions are significant at the $p$-value $<0.05$.

\begin{tabular}{ccccccc}
\hline \multirow{2}{*}{ Element } & \multicolumn{2}{c}{ OREAS 100a } & \multicolumn{2}{c}{ OREAS 101a } & \multicolumn{2}{c}{ OREAS 101b } \\
\cline { 2 - 6 } & Linear & Exponential & Linear & Exponential & Linear & Exponential \\
\hline $\mathrm{Al}$ & $0.38^{*}$ & $0.34^{*}$ & $0.23^{*}$ & $0.21^{*}$ & $0.53^{*}$ & $0.53^{*}$ \\
$\mathrm{Ti}$ & $\mathrm{ns}$ & $\mathrm{ns}$ & $\mathrm{ns}$ & $\mathrm{ns}$ & $\mathrm{ns}$ & $\mathrm{ns}$ \\
$\mathrm{Cr}$ & $\mathrm{ns}$ & $\mathrm{ns}$ & $\mathrm{ns}$ & $\mathrm{ns}$ & $\mathrm{ns}$ & $\mathrm{ns}$ \\
$\mathrm{Mn}$ & $0.35^{*}$ & $0.31^{*}$ & $0.29^{*}$ & $0.26^{*}$ & $0.32^{*}$ & $0.30^{*}$ \\
$\mathrm{Fe}$ & $0.26^{*}$ & $\mathrm{~ns}$ & $\mathrm{~ns}$ & $\mathrm{~ns}$ & $\mathrm{~ns}$ & $\mathrm{~ns}$ \\
$\mathrm{Cu}$ & $0.84^{*}$ & $0.85^{*}$ & $0.88^{*}$ & $0.90^{*}$ & $0.90^{*}$ & $0.92^{*}$ \\
$\mathrm{Zn}$ & $0.64^{*}$ & $0.57^{*}$ & $0.48^{*}$ & $0.45^{*}$ & $0.63^{*}$ & $0.59^{*}$ \\
$\mathrm{Rb}$ & $0.87^{*}$ & $0.90^{*}$ & $0.89^{*}$ & $0.92^{*}$ & $0.90^{*}$ & $0.92^{*}$ \\
$\mathrm{Sr}$ & $0.85^{*}$ & $0.84^{*}$ & $0.41^{*}$ & $0.41^{*}$ & $0,33^{*}$ & $0.37^{*}$ \\
$\mathrm{Zr}$ & $0.90^{*}$ & $0.93^{*}$ & $0.91^{*}$ & $0.93^{*}$ & $0.87^{*}$ & $0.89^{*}$ \\
$\mathrm{Nb}$ & $0.66^{*}$ & $0.63^{*}$ & $0.80^{*}$ & $0.81^{*}$ & $0.81^{*}$ & $0.81^{*}$ \\
\hline
\end{tabular}



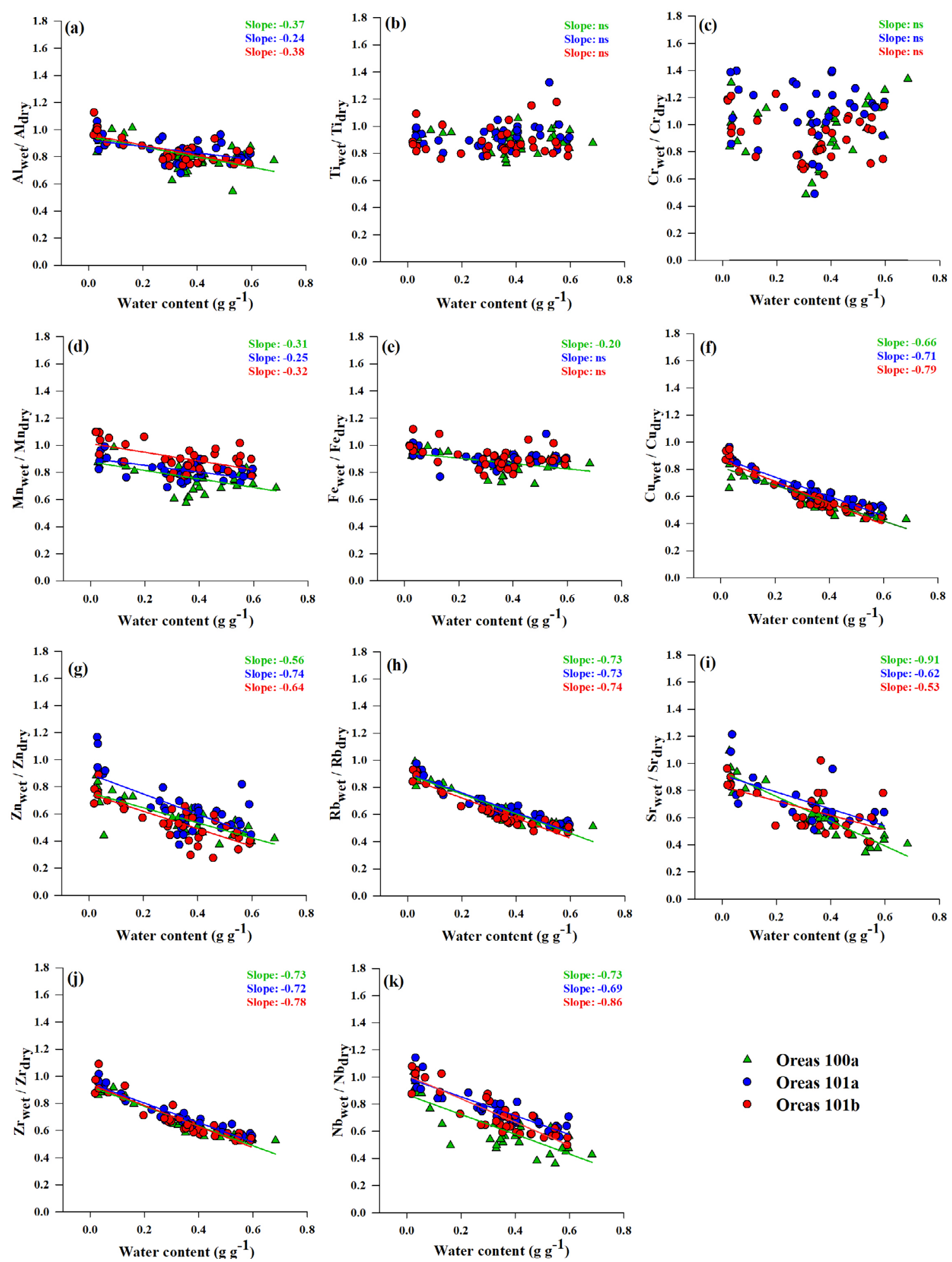

Figure 1: Effect of water content on $\mathrm{C}_{\text {wet }} / \mathrm{C}_{\mathrm{drr}}$ ratio for $\mathrm{Al}, \mathrm{Ti}, \mathrm{Cr}, \mathrm{Mn}, \mathrm{Fe}, \mathrm{Cu}, \mathrm{Zn}, \mathrm{Rb}, \mathrm{Sr}, \mathrm{Zr}$, and $\mathrm{Nb}$ of the three CRMs (OREAS 100a, OREAS 101a, and OREAS 101b) using pXRF; ns = not significant. 
group, which is more impacted than the $\mathrm{K} \alpha$ group, has $\mathrm{keV}$ values ranging from 0.928 to 2.169 . In the $\mathrm{K} \alpha$ group, $\mathrm{Cr}$, $\mathrm{Mn}$, and Fe have characteristic X-ray energy values higher than $5 \mathrm{keV}$ and Ti close to $5 \mathrm{keV}$, respectively. Only Al has a keV-value of 1.486 .

In a similar study, Schneider et al. (2015) studied the effect of water content on determination of 11 elements. $\mathrm{Fe}, \mathrm{Cu}, \mathrm{Mn}, \mathrm{Pb}, \mathrm{Rb}, \mathrm{Sr}$, and $\mathrm{Zn}$ showed the lowest $\sigma$ values (ranging from 0.87 to 0.99 ), and $\mathrm{Ba}$, $\mathrm{Cr}$, and $\mathrm{Sn}$ the highest values $(1.41,1.28$ and 1.03, respectively). Shuttleworth et al. (2014) assessed $\mathrm{Pb}$ in contaminated Histosols, comparing acid digestion method (US EPA 3051a) followed by inductively couple plasma optical emission spectrometry (ICP-OES) to pXRF analysis (in-situ and ex-situ). The authors found a significant difference between wet and dry samples on their results. However, the moisture-corrected data and in-situ pXRF analysis showed a strong correlation to ICP-OES results. Sahraoui and Hachicha (2017) assessed the concentrations of $\mathrm{Ca}, \mathrm{Mg}, \mathrm{Cd}, \mathrm{Cr}, \mathrm{Cu}, \mathrm{Ni}, \mathrm{Zn}, \mathrm{P}, \mathrm{Fe}$, $\mathrm{Mn}$ and $\mathrm{Pb}$ via pXRF in 60 soil samples (Tunísia) at different moisture: in-situ, oven-dried, $0.40 \mathrm{~g} \mathrm{~g}^{-1}(40 \%$ wt) and complete saturated. They found the elements may be differently impacted according to the water content, and the magnitude of the water content effect on pXRF results seems to be also related to its own content. For instance, Ribeiro et al. (2018) modelled the effect of water content on the determination of $\mathrm{SiO}_{2}$ and $\mathrm{Al}_{2} \mathrm{O}_{3}$ in tropical soils adjusting a power function. The effect of water content is more pronounced in the wettest samples (soil moisture $>0.20 \mathrm{~g} \mathrm{~g}^{-1}$ ). These findings corroborate to the recommendations of US EPA 6200 method in which it is reported that the pXRF results may be minimally impacted by moisture between 5 to $20 \%$.

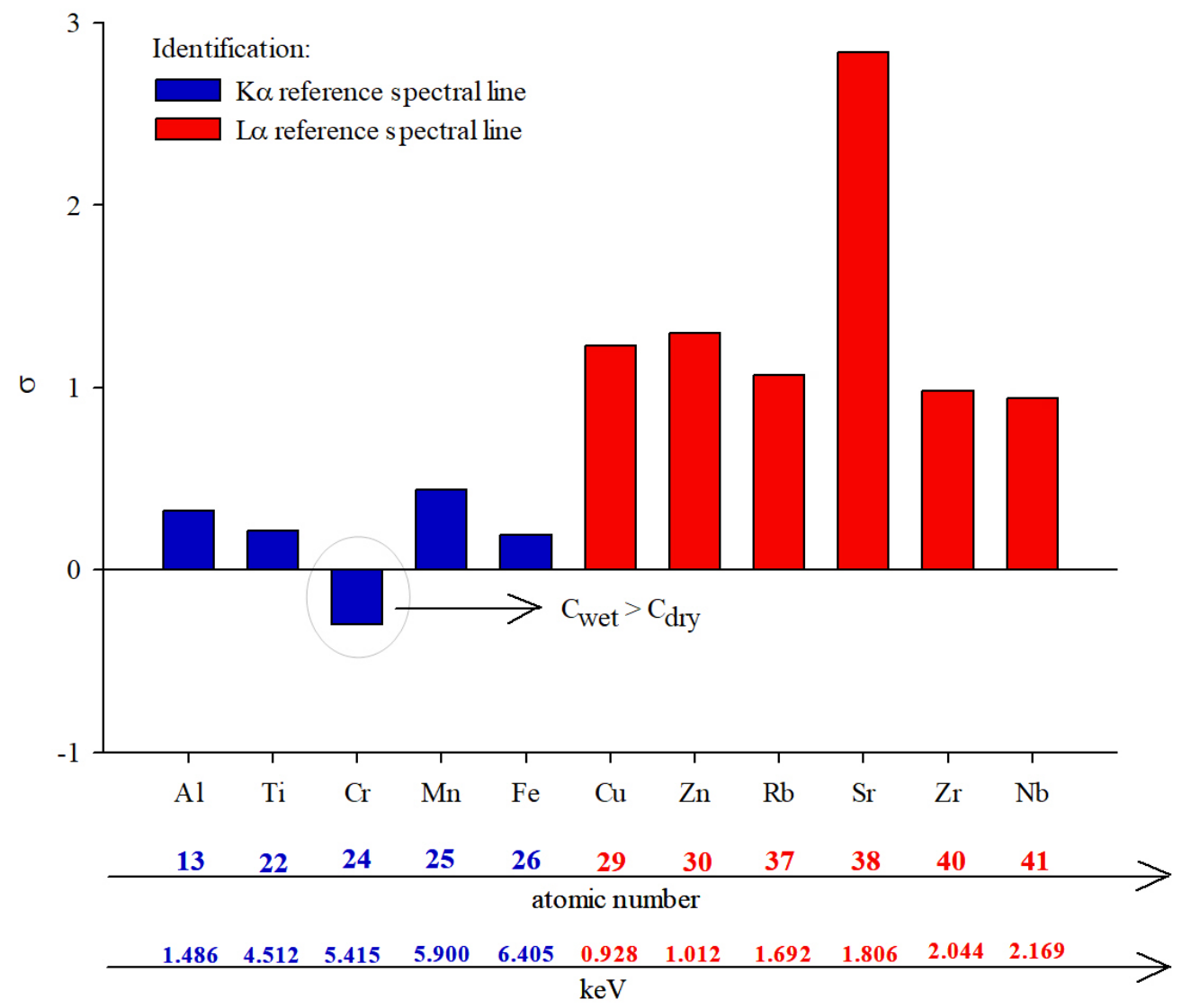

Figure 2: Attenuation coefficient ( $\sigma$ ) for $\mathrm{Al}, \mathrm{Ti}, \mathrm{Cr}, \mathrm{Mn}, \mathrm{Fe}, \mathrm{Cu}, \mathrm{Zn}, \mathrm{Rb}, \mathrm{Sr}, \mathrm{Zr}$, and $\mathrm{Nb}$ specified for $\mathrm{Ka}$ (blue) and $\mathrm{La}$ (red) Xrays characteristic energies, calculated for the maximum water content $\left(0.68 \mathrm{~g} \mathrm{~g}^{-1}\right)$. 


\section{CONCLUSIONS}

The qualitative elemental concentrations of the most assessed elements by pXRF significantly reduced linearly with increasing water content. Conversely to our hypothesis, it was not possible a modelling of the impact of water content, assessed by the attenuation coefficient, as function of atomic number. In this work, elements with highest atomic number and identified by $L \alpha$ spectral line $(\mathrm{Cu}, \mathrm{Zn}, \mathrm{Rb}, \mathrm{Sr}, \mathrm{Zr}$ and $\mathrm{Nb})$ were the most impacted by water content. $\mathrm{Ti}, \mathrm{Cr}$ and $\mathrm{Fe}$ were not influenced by water, and $\mathrm{Sr}$ was the most impacted element. Our findings contribute to $\mathrm{pXRF}$ users to identify the elements impacted or non-impacted by water content, contributing to decision-making before characterization of earth materials. Dry samples are required for the determination of the impacted elements via pXRF or by using moisturecorrected data.

\section{ACKNOWLEDGMENTS}

The authors are grateful to the following Brazilian research funding agencies: CAPES, CNPq and FAPEMIG (APQ-02613-18).

\section{REFERENCES}

BASTOS, R. O.; MELQUIADES, F. L.; BIASI, E. V. Correction for the effect of soil moisture on in situ XRF analysis using low-energy background. X-Ray Spectrometry, 41:304307, 2012.

BERGER, M.; ZOU, L.; SCHLEICHER, R. Analysis of sulfur in the Copper Basin and Muddy River sites. International Journal of Soil, Sediment and Water, 2:1-17, 2009.

CAPORALE, A. G. et al. Monitoring metal pollution in soils using portable-XRF and conventional laboratory-based techniques: Evaluation of the performance and limitations according to metal properties and sources. Science of the Total Environment, 643:516-526, 2018.

GAZLEY, M. F.; FISHER, L. A. A review of the reliability and validity of portable X-ray fluorescence spectrometry (PXRF) data. In: EDWARDS, A. C. Mineral resource and ore reserve estimation. Melbourne: The Australasian Institute of Mining and Metallurgy, 2014, p.69-82.

GE, L.; LAI, W.; LIN, Y. Influence of and correction for moisture in rocks, soils and sediments on in situ XRF analysis. X-Ray Spectrometry, 34:28-34, 2005.

HANGEN, E.; VIETEN, F. Influence of soil pore length upon portable X-ray fluorescence spectrometer measurements of elements in soils. Water, Air and Soil Pollution, 227:17, 2016.

HU, W. et al. Metals analysis of agricultural soils via portableX-ray fluorescence spectrometry. Bulletin of Environmental Contamination and Toxicology, 92:420-426, 2014.

HÜRKAMP, K.; RAAB, T.; VÖLKEL, J. Two and three-dimensional quantification of lead contamination in alluvial soils of a historic mining area using field portable X-ray fluorescence (FPXRF) analysis. Geomorphology, 110(1):28-36, 2009.

JENKINS, R. X-Ray Fluorescence Spectrometry. A WileyInterscience publication, 1932. 207p.

KALNICKY, D.; SINGHVI, R. Field portable XRF analysis of environmental samples. Journal of Hazardous Materials, 83:93-122, 2001.

KIDO, Y.; KOSHIKAWA, T.; TADA, R. Rapid and qualitative major element analysis method for wet fine-grained sediments using an XRF microscanner. Marine Geology, 229:209225, 2006.

LAIHO, J. V. P.; PERÄMÄKI, P. Evaluation of portable X-ray fluorescence (PXRF) sample preparation methods. Special Paper of the Geological Survey of Finland, 38:73-82, 2005.

MANCINI, M. et al. Tracing tropical parent material analysis via portable X-ray fluorescence ( $\mathrm{PXRF}$ ) spectrometry in Brazilian Cerrado. Geoderma, 337:718-728, 2019.

MARGUI, E.; GRIEKEN, R. V. X-ray Fluorescence Spectrometry and Related Techniques: An Introduction. New York: Momentum Press, 2013. 142p.

McNULTY, B. A. et al. Lithological discrimination of altered volcanic rocks based on systematic portable X-ray fluorescence analysis of drill core at the Myra Falls VHMS deposit, Canada. Journal of Geochemical Exploration, 193:1-21, 2018.

NEWLANDER, K. et al. Empirical study of the effect of count time on the precision and accuracy of pXRF data. Journal of Archaeological Science: Reports, 3:534-548, 2015.

PARSONS C. et al. Quantification of trace arsenic in soils by field-portable X-ray fluorescence spectrometry: Considerations for sample preparation and measurement conditions. Journal of Hazardous Materials, 262:12131222, 2013.

PEINADO, F. M. et al. A rapid field procedure for screening trace elements in polluted soil using portable X-ray fluorescence (PXRF). Geoderma, 159:76-82, 2010. 
PIOREK, S. On-site, in-situ characterization of contaminated soil and liquid hazardous waste with field portable $X$-ray analyzer- a cost effective approach In: GOTTLIEB, J. et al. Field Screening Europe. Dordrecht: Springer, 1997. p.329-333.

POTTS, P. J. Introduction, analytical instrumentation and application overview. In: POTTS, P. J.; WEST, M. Portable X-ray Fluorescence Spectrometry: Capabilities for In Situ Analysis. Cambrigde: The Royal Society of Chemistry, 2008. p.1-12.

RIBEIRO, B. T. et al. Portable X-ray fluorescence (pXRF) applications in tropical Soil Science. Ciência e Agrotecnologia, 41:245-254, 2017.

RIBEIRO, B. T. et al. The influence of soil moisture on oxide determination in tropical soils via portable X-ray fluorescence. Soil Science Society of America Journal, 82:632-644, 2018.

SAHRAOUI H.; HACHICHA, M. Effect of soil moisture on trace elements concentrations using portable X-ray fluorescence spectrometer. Journal of Fundamental and Applied Sciences, 9(1):468-484, 2017.

SANTANA, M. L. T. et al. Conditions affecting oxide quantification in unknown tropical soils via handheld X-ray fluorescence spectrometer. Soil Research, 56(6):648-655, 2018.

SCHNEIDER, A. R. et al. Comparison of field portable XRF and aqua regia/ICPAES soil analysis and evaluation of soil moisture influence on FPXRF results. Journal Soil and Sediments, 16:438-448, 2015.

SHUTTLEWORTH, E. L. et al. Assessment of lead contamination in peatlands using field portable XRF. Water, Air, and Soil Pollution, 225:1-13, 2014.

SILVA, S. H. G. et al. Soil weathering analysis using a portable $\mathrm{X}$-ray fluorescence (PXRF) spectrometer in an Inceptisol from the Brazilian Cerrado. Applied Clay Science, 162:2737, 2018.

SINNESAEL, M. et al. An integrated pelagic carbonate multi-

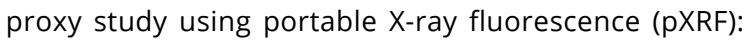
Maastrichtian strata from the Bottaccione Gorge, Gubbio, Italy. Cretaceous Research, 91:20-32, 2018.

STOCKMANN, U. et al. The effect of soil moisture and texture of Fe concentration using portable X-ray fluorescence spectrometers. In: HARTEMINK, A. E.; MINASNY, B. Digital Soil Morphometrics. Madison: Springer International Publishing Switzerland, 2016. p.63-71.

US EPA. Method 6200: Field portable X-ray fluorescence spectrometry for the determination of elemental concentrations in soil and sediment. 2007. 32p. Available in: <https://www.epa.gov/sites/production/ files/2015-12/documents/6200.pdf>. Access in: Mar, 9, 2018.

WEINDORF, D. C.; BAKR, N.; ZHU, Y. Advances in portable $X$-ray fluorescence (pXRF) for environmental, pedological, and agronomic applications. In: SPARKS, D. L. Advances in Agronomy. Delaware: University of Delaware, v. 128, p.1-45. 2014.

WEINDORF, D. C.; CHAKRABORTY, S. Portable X-ray fluorescence spectrometry analysis of soils. Methods of Soil Analysis, $1: 1-8,2016$

WIDANA, K. S.; PRIADI, B. Characteristics of trace elements in granitoid magmatism discrimination on Bangka Island. Eksplorium-Buletin Pusat Teknologi Bahan Galian Nuklir, 36(1):1-16, 2015.

YARBROUGH, L. D.; CARR, R.; LENTZ, N. X-ray fluorescence analysis of the Bakken and Three Forks Formations and logging applications. Journal of Petroleum Science and Engineering, 172:764-775, 2018. 